\title{
STRATEGI PEMANFAATAN SUMBER AIR DI KABUPATEN SIAK UNTUK PENGEMBANGAN UNIT PELAYANAN TEKNIS DAERAH (UPTD) AIR MINUM KABUPATEN SIAK
}

\author{
Dede Subhan, Usman M Tang, Ferry Fatnanta
}

\author{
Alumni Pascasarjana Ilmu Lingkungan Program Pascasarjana Universitas Riau, \\ Dosen Pascasarjana Ilmu Lingkungan Program Pascasarjana Universitas Riau, Pekanbaru, \\ Jl. Pattimura No.09.Gobah, 28131. Telp 0761-23742. \\ e-mail:subhan08dede@gmail.com \\ ABSTRAK
}

Tujuan dari penelitian ini adalah untuk Menganalisis kondisi ketersediaan sumber air baku, kondisi UPTD Air Minum dan kebijakan pemerintah daerah untuk memenuhi kebutuhan air bersih masyarakatnya serta kebijakan dan strategi pemanfaatan sumber air di Kabupaten Siak untuk pengembangan UPTD Air Minum Kabupaten Siak. Lokasi penelitian berada di Kabupaten Siak, Metode penelitian yang digunakan adalah metode survey. Hasil dari penelitian ini adalah Kondisi sumber air baku di kabupaten jumlahnya banyak namun kualitas airnya yang kurang baik. Belum adanya kebijakan berwawasan lingkungan. Permasalahan jarak, luas wilayah, sebaran penduduk, topografi, dan sumber listrik berakibat pada tingginya biaya perpipaan dan pemasangan aksesoris. Cakupan pelayanan UPTD Air Minum masih kecil dan Pendanaan juga masih bergantung kepada pemerintah daerah. Kelembagaan masih berbentuk UPTD. Dilihat dari aspek Oprasional, UPTD Air Minum Kabupaten Siak belum optimal. Aspek sumber daya manusia sudah baik. Aspek strategi menunjukan masyarakat merupakan prioritas utama dalam strategi pengembangan, setelah itu baru aspek lingkungan dan pemerintah yang menjadi prioritas kedua dan ketiga. Alternatif strategi yang bisa dilakukan adalah dengan meningkatkan infrastruktur, inovasi teknologi, Kerjasama dengan masyarakat dan pihak swasta, peningkatan pendanaan, Peningkatan kualitas kelembagaan, Pemnafaatan air permukaan, Penerapan perda tentang air minum

Kata Kunci: Air Baku, Air Bersih, UPTD Air Minum

\section{PENDAhULUAN}

Air merupakan kebutuhan pokok bagi manusia seperti untuk mandi, mencuci, memasak dan lainnya. Untuk mendukung pembangunan yang berkelanjutan, sektor air minum merupakan aspek pembangunan yang memiliki fungsi penting dalam menunjang tingkat kesejahteraan masyarakat, karena berkaitan dengan kesehatan, pola hidup, kondisi lingkungan permukiman serta kenyamanan dalam kehidupan sehari-hari. Pelayanan air minum yang baik tentunya akan memberikan dampak pada perbaikan sosial, ekonomi dan lingkungan. Sejalan dengan kebutuhan air bersih yang semakin meningkat sedangkan penyediaan air bersih yang semakin menurun bisa menyebabkan terjadinya krisis air bersih.

Berdasarkan Peraturan Pemerintah (PP) Nomor 16 tahun 2005 tentang Sistem Pengembangan Air Minum, sistem penyediaan air minum (SPAM) merupakan bagian dari pemanfaatan sumber daya air dan pengelolaan sanitasi sebagai salah satu bentuk perlindungan dan pelestarian terhadap sumber daya air, perlu dilaksanakan oleh Pemerintah dan/atau Pemerintah Daerah. Pengembangan SPAM yang merupakan tanggungjawab Pemerintah dan Pemerintah Daerah diselenggarakan dalam rangka mewujudkan kesejahteraan masyarakat dengan menjamin kebutuhan pokok air minum masyarakat yang memenuhi syarat kualitas, kuantitas, dan kontinuitas. Saat ini penanganan air minum di Kabupaten Siak berada dibawah pengelolaan Dinas Tata Ruang dan Cipta Karya Kabupaten Siak melalui UPT Air Bersih Kabupaten Siak. UPTD SPAM Kabupaten Siak dibentuk berdasarkan Peraturan Bupati Kabupaten Siak Nomor 32 Tahun 2013 tanggal 10 Oktober 2013 tentang Organisasi dan Tata Kerja Unit Pelaksana Teknis Dinas Sistem Penyediaan Air Minum pada Dinas Cipta Karya dan Tata Ruang Kabupaten Siak.

Sumber air baku untuk pelayanan air minum di Kabupaten Siak umumnya adalah dari sungai Siak, kecuali kota Minas yang diambil dari danau Takwana. Kondisi air sungai 
Siak sangat dipengaruhi oleh kegiatan di bagian hulu, disamping sifat dan kondisi airnya yang buruk. Kondisi ini menyebabkan tingginya biaya operasional untuk menghasilkan air minum yang layak konsumsi. Selain biaya pengolahan, proses distribusi air minum di Kabupaten Siak juga memerlukan biaya tinggi, karena kondisi penyebaran penduduk, jarak Instalasi ke permukiman serta kondisi topografi yang relatif datar (Dinas Pekerjaan Umum Provinsi Riau, 2014).

Meningkatnya jumlah penduduk akan mengakibatkan meningkatnya kebutuhan air bersih sehingga diperlukan upaya-upaya untuk memenuhi kebutuhan air bersih masyarakat. upaya-upaya tersebut dimulai dari ketersediaan air baku kemudian kelembagaan yang mengelola dan mendistribusikan air bersih serta strategi dan kebijakan pemanfaatan sumber daya air untuk pengembangan kedepannya.

\section{METODOLOGI PENELITIAN}

Waktu penelitian dilaksanakan pada bulan September sampai dengan bulan desember 2015. Tempat penelitian di Kabupaten Siak Sri Indrapura.

Bahan dan alat yang dipergunakan dalam penelitian ini adalah sebagai berikut:

1. Kamera (Canon EOS 600D) untuk mendokumentasikan informasi yang dianggap penting;

2. Alat tulis untuk mencatat hasil wawancara, observasi dan survey lapangan;

3. Kuesioner digunakan sebagai panduan wawancara memperoleh data dari responden terpilih secara langsung melalui proses komunikasi atau dengan mengajukan pertanyaan.

Penelitian ini dilakukan dengan metode penelitian deskriptif.

\section{HASIL DAN PEMBAHASAN}

Kondisi sumber air di Kabupaten Siak saat ini kondisinya kurang baik dikarenakan terjadinya pencemaran dan degradasi lingkungan yang semakin parah. Menutrut Bapeda Riau (2013), semakin lama sumber air yang ada di Kabupaten Siak akan semakin menurun kualitas maupun kuantitasnya dan apabila tidak ada tindakan yang nyata dari pihak terkait untuk mencegah kerusakan semakin parah bukan tidak mungkin sumber air di Kabupaten Siak akan semakin menipis dan tidak akan mencukupi lagi untuk kebutuhan masyarakat.

\section{Hidrologi}

Keadaan hidrologi di Kabupaten Siak dipengaruhi oleh sumber air yang berasal dari air permukaan dan air tanah, sumber air permukaan berasal da ri aliran sungai, danau dan tasik, sedangkan untuk air tanah berasal dari air tanah dangkal dan air tanah dalam.

2. Potensi air permukaan

Berdasarkan Peraturan Menteri Pekerjaan Umum No. 11A/PRT/M/2006 tentang Kriteria dan Penetapan Wilayah Sungai, maka sebagian besar wilayah Kabupaten Siak terletak dalam Wilayah Sungai Siak (WS Siak), sebagian kecil dari wilayah yang berada di bagian sebelah barat, terletak dalam Wilayah Sungai Rokan (WS Rokan), sedangkan sebagian kecil wilayah lainnya di sebelah selatan berada dalam Wilayah Sungai Kampar (WS Kampar).

Kabupaten Siak memiliki potensi air permukaan yang berasal dari sungai utama maupun dari anak-anak sungai yang mengalir pada masing-masing DAS bisa digunakan untuk sumber air baku pada sistem pelayanan Air Bersih / Air Minum. Pada aliran sungai utama dapat dipergunakan sebagai sumber air baku untuk sistem pelayanan air minum dalam sekala besar sedangkan untuk anak-anak sungai bisa digunakan sebagai sumber air baku untuk sistem pelayanan air bersih dalam skala kecil misalnya untuk sistem pelayanan air minum pedesaan. Berikut ini adalah luas DAS dan kondisi air permukaan di Kabupaten Siak

Sumber air permukaan di Kabupaten Siak memang cukup banyak namun dengan kualitas airnya yang kurang baik, sehingga membutuhkan pengolahan yang lebih intensif dan menghambat dalam proses pengolahan air sehingga kapasitas instalasi pengolahan air tidak bisa memproduksi air bersih dengan optimal dan menimbulkan idle capacity yang 
relatif cukup besar di setiap instalasi pengolahan air.

\section{Potensi air tanah}

Susunan batuan yang berkembang di wilayah Kabupaten Siak Keterdapatan air tanah di wilayah Kabupaten Siak ini adalah pada sistem air tanah dangkal (atau air tanah tidak tertekan) yang diharapkan berada pada kedalaman sekitar $25 \mathrm{~m}$ atau lebih di bawah permukaan tanah dan pada sistem air tanah dalam (atau air tanah tertekan/setengah tertekan) yang diharapkan berada pada kedalaman mulai dari $25 \mathrm{~m}$ sampai lebih dari $200 \mathrm{~m}$ di bawah permukaan tanah

Kabupaten Siak terdapat beberapa kecamatan yang tidak termasuk kedalam wilayah Cekungan Air Tanah. Dengan demikian di kecamatan ini potensi air tanahnya cukup kecil untuk dikembangkan sebagai sumber air baku. Selanjutnya untuk daerah yang memiliki potensi air tanah yang cukup besar dapat dikembangkan sebagai sumber air baku untuk memenuhi kebutuhan air domestik terutama sistem non perpipaan. Kebutuhan air pada tahun 2030 cukup tinggi ini memungkinkan terjadinya kekurangan air baku karena kualitas air Sungai Siak yang semakin menurun dan penggunaan air sungai oleh industri, ini sama seperti yang terjadi di Kabupaten Rembang (Hidayat, 2013) jumlah kebutuhan air yang sangat tinggi sehingga diperlukan upaya untuk penambahan cadangan air agar bisa digunakan ketika kebutuhan akan air semakin meningkat

Indikator penilaian/evaluasi kinerja UPTD Air Minum Kabupaten Siak menggunakan empat aspek pengukuran yaitu aspek keuangan, pelayanan, oprasional, dan sumberdaya manusia dari UPTD Air Minum Kabupaten Siak, untuk memberikan kecermatan maka dalam melakukan evaluasi masingmasing aspek dirinci:

1) Aspek Keuangan

UPTD Air Minum Kabupaten Siak adalah Unit Pelaksana Teknis Dinas di bawah struktur Dinas Tata Ruang Dan Cipta Karya. UPTD tidak dapat menggunakan pendapatan yang diperolehnya secara langsung, pendapatan UPTD SPAM Kabupaten Siak disetor langsung ke kas daerah. Maka dalam pengelolaannya, tiap tahun Kepala Dinas PU mengusulkan biaya O\&M untuk dialokasikan dalam DIP Daerah.

Tabel 1. Jumlah Realisasi PAD SPAM Kabupaten Siak

\begin{tabular}{lrrr}
\hline \multicolumn{1}{c}{ Unit SPAM } & \multicolumn{3}{c}{ JUMLAH REALISASI PAD (Rp) } \\
\hline Siak & \multicolumn{1}{c}{ 2011 } & \multicolumn{1}{c}{ 2012 } & \multicolumn{1}{c}{013} \\
Mempura & 1.994 .099 .800 & 2.263 .481 .000 & 2.740 .002 .750 \\
Tualang & 238.899 .500 & 128.763 .500 & 242.012 .250 \\
Sungai Apit & 150.267 .500 & 156.022 .500 & 129.646 .000 \\
Minas & 77.622 .600 & 123.320 .500 & 176.544 .750 \\
Koto Gasib & 507.161 .250 & 707.550 .750 & 661.480 .500 \\
Kandis & 86.436 .000 & 188.403 .250 & 298.556 .500 \\
\hline Jumlah & 167.566 .750 & 216.194 .500 & 179.608 .000 \\
\hline
\end{tabular}

Sumber: UPTD SPAM Kabupaten Siak, 2014 Laporan Keuangan UPTD Pemkab Siak

Dilihat dari realisasi PAD SPAM Kabupaten Siak per Ibu Kota Kecamatan (IKK) setiap tahunnya, IKK Siak memiliki pendapatan paling tinggi dibandingkan dengan IKK lainnya. Total penerimaan dan setoran PAD berasal dari penerimaan air dan penerimaan non air. Penerimaan air berdasarkan total tagihan pelanggan yang meliputi pelanggan non niaga, niaga dan industri. Sementara penerimaan non air berasal dari penerimaan mobil tangki, denda, biaya pemasangan, biaya penyambungan kembali dan biaya balik nama. Setiap tahunnya, IKK Siak mendapatkan penerimaan paling tinggi diantara IKK lain, hal ini sebanding dengan jumlah SR, dimana SR IKK Siak mencapai 3.412 SR, namun karena sistem 
kelembagaan SPAM Kabupaten Siak masih UPTD yang menjadikan UPTD SPAM Kabupaten Siak tidak dapat menggunakan pendapatan yang diperoleh karena harus disetor ke kas daerah dan UPTD SPAM Kabupaten Siak tidak dapat mengelola keuangannya sendiri.

2) Aspek Pelayanan

Aspek pelayanan yang dilihat dan diteliti meliputi tiga komponen utama yaitu:

1. Cakupan pelayanan teknis, berikut ini adalah perhitungan dari cakupan pelayanan UPTD Air Minum Kabupaten Siak.

Tabel. 2 Cakupan Pelayanan

\begin{tabular}{ll}
\hline \multicolumn{1}{c}{ Uraian } & \multicolumn{1}{c}{ Nilai } \\
\hline Penduduk Terlayani & 35.390 \\
Jumlah Penduduk Pelayanan & 423.271 \\
Cakupan Pelayanan & $7,19 \%$ \\
\hline S
\end{tabular}

Sumber: Data Primer 2015

Dilihat dari hasil perhitungan, cakupan wilayah pelayanan UPTD Air minum Kabupaten Siak masih rendah.

2. Pertumbuhan pelanggan digunakan untuk mengetahui berapa perosentasi peningkatan jumlah pelanggan dalam satu tahun, berikut ini adalah hasil perhitungan jumlah pertumbuhan pelanggan untuk UPTD Air Minum Kabupaten Siak dari tahun 2013 sampai 2014.

Tabel 3. Pertumbuhan Pelanggan

\begin{tabular}{cl}
\hline \multicolumn{1}{c}{ Uraian } & \multicolumn{1}{c}{ Nilai } \\
\hline Jumlah Pelanggan Tahun 2014 & 7.078 \\
Jumlah Pelanggan Tahun 2013 & 6.145 \\
Pertumbuhan Pelanggan & $15,18 \%$ \\
\hline Sumber: Data Primer 2015 &
\end{tabular}

Dilihat dari hasil perhitungan, pertumbuhan pelanggan cukup tinggi karena mencapai angka diatas $10 \%$ untuk jumlah pertumbuhan pelanggannya.

3. Konsumsi air domestik, indikator ini menggambarkan tingkat konsumsi pelanggan rumahtangga terhadap air UPTD Air Minum perbulan perpelanggan. Berikut ini adalah hasil perhitungan konsumsi air domestik per bulan di UPTD Air Minum Kabupaten Siak.

Tabel 4. Konsumsi Air Domestik

\begin{tabular}{ll}
\hline \multicolumn{1}{c}{ Uraian } & \multicolumn{1}{c}{ Nilai } \\
\hline Jumlah Air Terjual $\left(\mathrm{M}^{3}\right)$ & 123.293 \\
Jumlah Pelanggan Domestik (SR) & 6.748 \\
Konsumsi Air Domestik (M $\left.{ }^{3} / \mathrm{Pel}\right)$ & 18.27 \\
\hline Sumber: Data Primer 2015 &
\end{tabular}

Dari hasil perhitungan, penggunaan air pada setiap pelanggan masih rendah masih berada dibawah $20 \mathrm{M}^{3} /$ Pelanggan.

3) Aspek Oprasional

Aspek oprasional yang akan diteliti terdiri dari empat komponen yaitu:

1. Efisiensi Produksi berikut ini adalah hasil perhitungan dari tingkat efisiensi produksi UPTD Air Minum Kabupaten Siak.

Tabel. 5 Efisiensi Produksi

\begin{tabular}{ll}
\hline \multicolumn{1}{c}{ Uraian } & \multicolumn{1}{c}{ Nilai } \\
\hline Realisasi Produksi $\left(\mathrm{M}^{3}\right)$ & 2.796 .924 \\
Kapasitas Terpasang $\left(\mathrm{M}^{3}\right)$ & 9.776 .160 \\
Efisiensi Produksi $(\%)$ & $29 \%$ \\
\hline Sumber: Data Primer 2015 &
\end{tabular}

Hasil perhitungan efisiensi produksi menunjukan bahwa idle capacity yang ada masih tinggi.

2. Tingkat kehilangan air, untuk mengukur efisiensi sistem distribusi terhadap penjualan air berikut ini adalah hasil dari perhitungan tingkat kehilangan air yang menjadi persoalan dari UPTD Air Minum Kabupaten Siak.

Tabel 6. Tingkat kehilangan air

\begin{tabular}{ll}
\hline Uraian & Nilai \\
\hline Distribusi Air & $2.522 .880 \mathrm{M}^{3}$ \\
Air Berrekening & $1.258 .128 \mathrm{M}^{3}$ \\
Tingkat Kehilangan Air & $50,13 \%$ \\
\hline
\end{tabular}

Sumber: Data Primer 2015

Untuk jumlah kehilangan air masih cukup tinggi karena lebih dari setengah kapasitas produksi air tidak terjual, hal ini bisa menyebabkan kerugian bagi UPTD Air Minum Kabupaten Siak. 
3. Jam operasi pelayanan, untuk mengukur efisiensi sistem secara keseluruhan dan kaitannya dengan kontinuitas pelayanan, berikut ini hasil perhitungan jam oprasi pelayanan UPTD Air Minum Kabupaten Siak (Tabel 5).

Tabel 6. Jam Oprasi Pelayanan

\begin{tabular}{lr}
\hline \multicolumn{1}{c}{ Uraian } & \multicolumn{1}{c}{ Nilai } \\
\hline Waktu Distribus 1 Tahun & 3.285 \\
Pembagi & 365 \\
Jam Oprasi Pelayanan & 9 \\
Sumber: Data Primer 2015 &
\end{tabular}

Jam oprasional untuk distribusi ke pelanggan masih cukup rendah hanya rata-rata Sembilan jam untuk seluruh SPAM IKK yang beroprasi.

4) Aspek Sumber Daya Manusia

Aspek sumber daya manusia yang akan dilihat dan diteliti terdiri dari dua komponen yaitu:

1. Rasio Pegawai terhadap 1000 pelanggan, untuk mengukur efisiensi penggunaan tenaga kerja dalam melayani setiap 1000 pelanggan dan berikut ini adalah hasil perhitungan dari rasio pegawai yang ada di UPTD Air Minum Kabupaten Siak dilihat dari perbandingan antara jumlah pegawai dan jumlah pelanggan.

Tabel 7. Rasio Pegawai

\begin{tabular}{ll}
\hline \multicolumn{1}{c}{ Uraian } & \multicolumn{1}{c}{ Nilai } \\
\hline Jumlah Pegawai & 120 \\
Jumlah Pelanggan/1000 & 27,57 \\
Rasio Pegawai & 4,35 \\
\hline
\end{tabular}

Sumber: Data Primer 2015

Rasio pegawai yang ada rata-rata setiap 1000 pelanggan dilayani oleh 4-5 pegawai ini menunjukan jumlah yang cukup rendah sehingga diperlukan penambahan pegawai agar perbandingannya menjadi 1:100.

2. Rasio Pendidikan dan Pelatihan Pegawai, mengukur kepedulian perusahaan untuk meningkatkan kompetensi pegawai dan berikut ini adalah hasil perhitungan dari rasio pendidikan dan pelatihan pegawai yang ada di UPTD Air Minum Kabupaten Siak.

Tabel. 8 Rasio Pegawai

\begin{tabular}{ll}
\hline Uraian & Nilai \\
\hline Jumlah Pegawai & 120 \\
Jumlah Pegawai Ikut Diklat & 113 \\
Rasio Diklat Pegawai & $94,17 \%$ \\
\hline
\end{tabular}

Sumber: Data Primer 2015

Jumlah pegawai yang mengikuti diklat cukup banyak dari hasil perhitungan rasio diklat pegawai mencapai $94,17 \%$ ini menunjukan keseriusan dari UPTD Air Minum Kabupaten Siak untuk meningkatkan kemampuan yang dimiliki oleh setiap pegawainya agar pelayanan terhadap masyarakat semakin optimal.

Tingkat pelayanan Air Minum di Kabupaten Siak masih rendah dibandingkan dengan daerah lain seperti di semarang (Maryono, 2007) untuk pelayanan masyarakat miskin saja sudah mencapai diatas $40 \%$ dibandingkan di Kabupaten Siak yang hanya berada di bawah $10 \%$.

Hasil dari analisis yang telah dilakukan terhadap tiga kriteria menunjukan untuk melakukan pengembangan UPTD Air Minum Kabupaten Siak dengan cara memanfaatkan sumber air yang ada maka yang prioritas utama adalah aspek masyarakat. ini ditunjukan dengan bobot tertinggi yaitu sebesar 540 atau dengan presentase sebesar $54,0 \%$, aspek lingkungan dengan bobot sebesar 297 atau dengan presenatse sebesar $29,7 \%$, aspek pemerintah dengan bobot sebesar 163 atau dengan presentase sebesar $16,3 \%$, dengan nilai inconsistency 0,0087 yaitu lebih kecil dari 0,1 maka hasilnya sudah dianggap konsisten. Masyarakat merupakan aspek yang sangat penting karena semua kegiatan yang dilakukan sasaran utamanya adalah masyarakat, sehingga sangat penting untuk dibahas dan dijadikan target utama untuk pengembangan UPTD Air Minum Kabupaten Siak.

Aspek kedua adalah aspek lingkungan karena dari lingkungan yang memasok kebutuhan air baku untuk diolah menjadi air bersih yang akan disalurkan kepada masyarakat. Semakin terjaga kualitas 
lingkungannya maka akan semakin baik pula sumber air bakunya.

Aspek yang ketiga adalah aspek pemerintahan. Campur tangan pemerintah diharapkan dapat membuat kegiatan UPTD Air Minum berjalan dengan lancar dan baik.

Alternatif strategi pemanfaatan sumber daya air di Kabupaten Siak untuk pengembangan UPTD Air Minum Kabupaten Siak adalah tindakan yang dapat membantu meningkatkan kinerja UPTD Air Minum sehingga masyarakat di Kabupaten Siak dapat terlayani dengan optimal. Berkaitan dengan sasaran-sasaran yang ingin dicapai dari berbagai aspek dalam strategi pemanfaatan sumber daya air di Kabupaten Siak untuk pengembangan UPTD Air Minum Kabupaten Siak, maka ada beberapa alternatif strategi yang dapat dilakukan:

1. Peningkatan Infrastruktur

2. Inovasi Teknologi

3. Kerjasama dengan Pihak Swasta dan masyarakat

4. Peningkatan Pendanaan

5. Peningkatan Kelembagaan

6. Pemanfaatan Air Permukaan

7. Penerapan Perda Tentang Air Minum

Prioritas utama dalam alternatif strategi yang pertama adalah meningkatkan infrastruktur dengan bobot 198 kemudian dengan inovasi teknologi dengan bobot 157 , kerjasama dengan pihak swasta dan masyarakat dengan bobot 156 , peningkatan pendanaan dengan bobot 154, peningkatan kualitas kelembagaan dengan bobot 135 , pemanfaatan air permukaan dengan bobot 106, dan penerapan perda tentang air minum dengan nilai bobot 92 .

1. Peningkatan Infrastruktur

Peningkatan infrastruktur adalah peningkatan pembangunan sarana dan prasarana untuk penunjang kebutuhan pelayanan air minum di Kabupaten Siak. Peningkatan infrastruktur yang bisa dilakukan diantaranya adalah dengan menambah Sistem Pengolahan Air Minum Ibu Kota Kecamatan (SPAM IKK) yang pada saat ini telah terbangun di 10 kecamatan dan terdapat empat kecamatan lagi yang belum terlayani.
Selain membangun SPAM IKK juga bisa dengan memanfaatkan sumber air tanah dengan membangun SPAM Komunal dengan pembuatan sumur artesis di setiap titik yang dibutuhkan untuk memenuhi kebutuhan air bersih masyarakat yang belum terlayani oleh SPAM IKK dari masing-masing kecamatan. Ini bisa dilakukan karena sesuai dengan Peraturan Pemerintah No. 16 Tahun 2005 tentang Pengembangan Sistem Penyediaan Air Minum, pengembangan SPAM bisa dengan sistem jaringan perpipaan dan/atau bukan jaringan perpipaan SPAM dengan jaringan perpipaan sebagaimana dimaksud dapat meliputi unit air baku, unit produksi, unit distribusi, unit pelayanan, dan unit pengelolaan. Sedangkan untuk SPAM dengan non perpipaan meliputi sumur dangkal, sumur pompa tangan, bak penampungan air hujan, terminal air, mobil tangki air, instalasi air kemasan, atau bangunan perlindungan mata air. Peningkatan infrastruktur untuk pemenuhan kebutuhan air bersih di Kabupaten Siak sangat dimungkinkan dikarenakan Kabupaten Siak memiliki PAD yang cukup besar dan bisa dialokasikan untuk meningkatkan infrastruktur pemenuhan kebutuhan air bersih.

2. Inovasi Teknologi

Seperti yang dijelaskan dalam Peraturan Pemerintah No. 33 Tahun 2011 tentang Kebijakan Nasional Pengelolaan Sumber Daya Air, bahwa Ilmu pengetahuan dan teknologi pengelolaan sumber daya air yang terus dikembangkan oleh negara lain merupakan tantangan bagi Indonesia agar tidak mengalami ketertinggalan. Penelitian, pengembangan ilmu pengetahuan dan penerapan teknologi serta peningkatan sumber daya manusia sangat diperlukan, agar Indonesia lebih mampu dan mandiri dalam pengelolaan sumber daya air.

3. Kerjasama Pemerintah dan Swasta dan masyarakat

Kerjasama antara pemerintah dan masyarakat baik dari segi kerjasama permodalan maupun pemberdayaan masyarakat seperti pada program PAMSIMAS

Pada Febuari 2015 Mahkamah Konstitusi telah membatalkan Undang-undang Sumber Daya Air Tahun 2004, sehingga lembaga 
pemerintah memiliki otoritas kuat terhadap sumberdaya air. Ini berarti usaha penyediaan air bersih bisa dikelola oleh tingkat desa yang dikenal sebagai Badan Usaha Milik Desa (BUMDes),. Namun BUMDes sendiri harus sesuai dengan kebutuhan dan potensi desa seperti yang tercantum dalam Peraturan Pemerintah No. 72 Tahun 2005 tentang Desa.

4. Peningkatan Pendanaan

Peningkatan pendanaan adalah menambah dana oprasional untuk kegiatan UPTD Air Minum Kabupaten Siak. Untuk meningkatkan pendanaan UPTD Kabupaten Siak dapat melakukannya dengan alternatif pembiayaan seperti:

1) Pinjaman Perbankan

2) Peningkatan peran serta swasta melalui kerjasama pemerintah dan swasta

3) Bussines to bussines (B to B)

4) Corporate Social Responsibility (CSR)

5) Pusat Investasi Pemerintah

6) Obligasi Daerah Bantuan

7) Hibah Masyarakat Berpenghasilan Rendah (MBR)

5. Peningkatan Kualitas Kelembagaan

Meningkatkan kapasitas lembaga pengelola air minum seperti strategi ditingkat nasional dan kebijakan/landasan hukum. Para stakeholder dalam kegiatan ini yaitu pengguna dan pemelihara pelayanan air, sehingga hal ini menentukan keberhasilan kegiatan tersebut, karena untuk memajukan suatu institusi kelembagaannya sendiri harus jelas dan tidak tergantung kepada pemerintah.

6. Pemanfaatan Air Permukaan

Memanfaatkan air yang berada di atas permukaan tanah sebagai air baku untuk diolah menjadi air bersih, seperti air sungai baik dari Sungai Siak maupun dari anak Sungai Siak yang memiliki debit yang cukup untuk dijadikan sebagai air baku, kemudian danaudanau dan tasik yang ada di Kabupaten Siak.

Strategi pengembangan UPTD Air Minum Kabupaten Siak yang pertama yang didahulukan adalah peningkatan infrastruktur, berbeda dengan yang dilakukan di Kabupaten Rembang (Hidayat, 2013) yang menjadi prioritas utama adalah dengan mengefisiensikan pemakaian karena kebutuhan air yang sangat tinggi sehingga diperlukan penambahan ketersediaan air yang tinggi pula, dan penambahan cadangan air jumlahnya terbatas maka yang jadi strategi prioritas adalah mengefisiensikan pemakaian. Berbeda dengan kabupaten siak yang jumlah pemakaiannya masih rendah dan cakupan pelayanan juga masih sedikit sehingga strategi yang diprioritaskan adalah peningkatan infrastruktur

\section{KESIMPULAN}

Dari hasil analisis yang telah dilakukan, maka dapat ditarik kesimpulan sebagai berikut:

1. Kondisi sumber air baku untuk air bersih di kabupaten jumlahnya cukup banyak namun dengan kualitas air yang kurang baik. Belum adanya kebijakan berwawasan lingkungan yang berbasis masyarakat untuk menyelamatkan sumber air.

2. Permasalahan yang terjadi UPTD Air Minum Kabupaten Siak adalah jarak, luas wilayah, sebaran penduduk, topografi, dan sumber listrik, cakupan pelayanannya masih kecil dan juga memiliki masalah pendanaan. Kelembagaan yang masih berbentuk UPTD. Dari aspek Oprasional, UPTD Air Minum Kabupaten Siak masih belum optimal, karena Efisiensi produksi yang masih rendah dan tingkat kehilangan air yang tinggi serta rata-rata waktu pelayanan hanya selama Sembilan jam per hari. Aspek sumber daya manusia untuk pendidikan dan pelatihan sudah baik hanya perbandingan jumlah tenaga kerja yang masih kurang dan harus di tambah lagi sehingga perbandingannya menjadi 1 berbanding 100 .

3. Hasil analisis yang telah dilakukan, aspek strategi menunjukan masyarakat merupakan prioritas utama dalam strategi pengembangan sehingga pelayanan terhadap masyarakat merupakan hal utama dalam pengelolaan UPTD Air Minum, setelah itu baru aspek lingkungan dan pemerintah . Alternatif strategi yang bisa dilakukan adalah dengan meningkatkan infrastruktur agar seluruh masyarakat dapat terlayani dan inovasi teknologi 
diperlukan agar air yang dihasilkan memiliki kualitas yang lebih baik dengan biaya pengolahan air yang kecil, namun untuk melaksanakan peningkatan infrastruktur harus sejalan dengan peningkatan pendanaan karena memerlukan dana yang besar untuk meningkatkan kualitas pelayanan, ada beberapa alternatif pendanaan yang bisa dilakukan namun masih terganjal oleh sistem kelembagaan sehingga kualitas kelembagaan harus ditingkatkan. Perlindungan terhadap lingkungan harus dilakuakan agar ketersediaan air baku bisa terus terjaga, perlindungan terhadap lingkungan yang bisa dilakuakan adalah dengan menggunakan air permukaan dan mengurangi penggunaan air tanah selain itu juga jumlah air permukaan lebih tinggi dibandingkan dengan air tanah karena Kabupaten Siak memiliki banyak sumber air permukaan yang berasal dari sungi siak dan anak sungai siak yang bisa dijadikan sebagai sumber air baku, dan untuk menjaga agar pelayanan air minum di Kabupaaten Siak terpenuhi secara kualitas, kuantitas dan kontinuitasnya maka pemerintah harus membuat peraturan yang mengatur tentang perlindungan sumber daya air seperti Peraturan Daerah Kabupaten Siak No. 10 Tahun 2010 tentang Ijin Pemanfaatan Sumber Daya Air.

\section{DAFTAR PUSTAKA}

Badan perencanaan pembangunan daerah Provinsi Riau. 2013.Penyusunan Daya Dukung dan Daya Tampung Lingkungan Hidup Provinsi Riau. Pekanbaru, Riau (Tidak dipublikasikan)

Peraturan Daerah Kabupaten Siak No. 10 Tentang Izin Pemanfaatan Sumber Daya Air, Sekretariat Daerah Kabupaten Siak, Siak Sriindrapura

Peraturan Pemerintah No. 16 Tahun 2005 tentang Pengembangan Sistem Penyediaan Air Minum. Sekretariat Negara, Jakarta

No. 72 Tahun 2005 tentang Desa. Sekretariat Negara, Jakarta

Peraturan Presiden No. 33 Tahun 2011 tentang Kebijakan Nasional Pengelolaan Sumber Daya Air. Sekretariat Negara, Jakarta

Menteri Pekerjaan Umum, RI. 2006 Peraturan Pekerjaan Umum No. 11A/PRT/M/2006 tentang Kriteria dan Penetapan Wilayah Sungai. Sekretariat Negara, Jakarta

Hidayat, G. 2013. Kajian optimalisasi dan Strategi Sumber Daya Air di Kabupaten

Rembang Jawa Tengah. Tesis, Prodi Ilmu Lingkungan Program Pasca Sarjana Universitas Diponegoro, Semarang (Tidak diterbitkan)

Maryono, 2007. Menilai Aksesibilitas Air Minum (Studi Kasus: Aksesibilitas Air Bersih Bagi Masyarakat Miskin di Kota Semarang). Jurnal Presipitasi, 3(1): 8692 